\title{
Öğretmenlerin Uzaktan Eğitimin Yararına İliş̧kin Algılarının İncelenmesi
}

\author{
Examining Teachers' Perceptions of the Benefit of Distance Education
}

\author{
İzzet KARACA ${ }^{[1]}$ Nahide KARACA[2] \\ Numan KARAMUSTAFAOĞLU[3] Mustafa ÖZCAN[4]
}

Başvuru Tarihi:10 Ocak 2021

Kabul Tarihi:20 Şubat 2021

Coronavirüs (Covid-19) pandemisi tüm alanları etkilediği gibi eğitimi de etkileyerek köklü değişikliklere sebep olmuştur. Tüm dünyada olduğu gibi Türkiye'de de yüzyüze eğitime ara verilerek uzaktan eğitim sürecine geçilmiştir. Milli Eğitim Bakanlığı yaklaşık bir milyon öğretmen, yönetici ve çalışanı ile bu süreci yürütmeye çalışmaktadır. Uzaktan eğitimin yarar sağlama düzeyini belirlemek için, bu sürecin en önemli yürütücüleri olan öğretmenlerin görüşleri büyük önem taşımaktadır. Bu çalışma ile Sinop ili Boyabat ilçesinde uzaktan eğitim sürecinde görev alan, 139 kadın, 103 erkek toplam 242 öğretmenin uzaktan eğitim sürecinin yarar algı düzeyleri ve bu düzeyin çeşitli faktörler bakımından incelenmesi yapılmıştır. Ölçme aracı iki bölümden oluşmaktadır. Birinci bölüm; demografik bilgileri, ikinci bölüm ise yarar algı düzeyini belirlemeye yöneliktir. Araştırma sonuçlarına göre öğretmenlerin uzaktan eğitim yarar algıları orta düzeyde çıkmıştır. Bu yarar algıları ile cinsiyet, öğrenim durumu ve kıdem yılı arasında anlamlı bir farklılık gözlemlenmezken, görev yapılan kademede, anaokulunda görev yapan öğretmenler lehine anlamlı bir farklılık olduğu görülmüştür. Araştırma, uzaktan eğitimin etkililik düzeyini belirlemesi açısından önemli görülmektedir.

Anahtar Kelimeler: pandemi, Covid 19, coronavirüs, uzaktan eğitim, yarar algısı

The coronavirus (Covid-19) pandemic has affected all areas and has caused radical changes by affecting education. Search for the training as well as all over the world face to face in Turkey has started to distance education process. The Ministry of National Education is trying to carry out this process with approximately one million teachers, managers and employees. In order to determine the level of benefit of distance education, the opinions of teachers, who are the most important drivers of this process, are of great importance. With this study, a total of 242 teachers, 139 women and 103 men, who took part in the distance education process in the city of Boyabat, Sinop, were examined in terms of benefit perception levels and various factors. The measuring tool consists of two parts. First part; demographic information, the second part is about the level of benefit perception. According to the results of the research, the distance education benefit perception of the teachers was found to be moderate. While no significant difference was observed between these perceptions of benefit and gender, educational status and years of seniority, it was observed that there was a significant difference in favor of teachers working in kindergarten at the level of duty. The research is considered important in determining the effectiveness of distance education.

Keywords: pandemic, Covid 19, coronavirüs, distance education, perception of benefit 


\section{GİRIŞ}

$\mathrm{U}$

zaktan eğitim kavramı, pandemi süreci ile birlikte gerek eğitim hayatımızda gerekse sosyal hayatımızda önemli yer tutan bir kavram haline gelmiștir. Genel anlamda, farklı mekânlarda bulunan öğretmen ve öğrencilerin, teknolojik imkânlarla etkileşim sağlama yöntemleri olarak tanımlanan uzaktan eğitim, örgün ve yaygın eğitimin en önemli yöntemi haline gelmiştir (İşman, 2008). Eğitim imkânlarının çeşitlenmesi, iş hayatıyla birlikte eğitim hayatının da devam etmesi, bireylerin eğitimden eşit olarak yararlanması, hayat boyu öğretimin devam etmesi, eğitim ile teknolojiyi bir arada kullanarak çok boyutlu yaklaşımların sağlanması, düşük maliyet yüksek etkililikle bireysel ve toplumsal eğitim sağlanması için uzaktan eğitim uygulamaları önemli ve faydalı bir yaklaşımdır (Alkan, 1997). Uzaktan eğitim bazen teknolojik gelişmelerle birlikte eğitim öğretimin kalitesini artırmak için yapılırken bazen de içinde bulunulan olumsuz bir durumda eğitim öğretim faaliyetlerinin devamlılığını sağlamak için kullanılan bir yöntem olarak karşımıza çıkmaktadır.

Yaklaşık iki yüzyıl kadar geçmişi bulunan uzaktan eğitim, günümüzde bireylerin eğitim ihtiyaçlarını karşılamak için kullanılan alternatif bir yöntemdir (Yenal, 2009). Yapılan araştırmalar uzaktan eğitimin aslında ihtiyaç neticesi olarak ortaya çıktığını göstermektedir. Fiziki ve maddi şartların yetersizliği ülkeleri uzaktan eğitim uygulamalarına yönlendirmiştir (Kırık,2014). Okula devam edebilmenin önüne engeller çıtıkça, zaman ve mekân kavramını ortadan kaldırarak eğitime devamı sağlayabilmek için de uzaktan eğitim yöntemleri tercih edilmiştir. Uzaktan eğitimin anılan durumlarda faydaları görülmeye başlanınca, farklı amaçlar için de kullanılmaya başlanmıştır. Bunların başında eğitimin kalitesinin artırılması gelmektedir. Özellikle internet kullanımının yaygınlaşmasına bağlı olarak uzaktan eğitim bireylere daha zengin öğrenme ortamları sunmaktadır. Bununla birlikte bireysel farklılıkları dikkate alarak ilgi ve yeteneklere göre öğretimi bireyselleştirerek eğitimin bireysellik ilkesinin tam olarak yerine getirilmesini sağlamaktadır. Bu amaçlar için daha çok yükseköğretimde uzaktan eğitim tercih edilmektedir. Son yıllarda, açılan lisans ve lisansüstü programlar ile sertifika programlarının sayısı ve çeşitliliği bunun en önemli göstergesidir. Ancak temel eğitim ve orta öğretimde coronavirüs (Covid-19) pandemisi dönemine kadar ciddi manada uzaktan eğitim faaliyeti görülmemiştir.

2019 yılının sonlarında başlayarak 2020 yılı itibariyle tüm dünyayı etkisi altına alan coronavirüs (Covid-19), Türkiye'de ilk olarak 10 Mart 2020 tarihinde görülmüştür. Dünya Sağlık Örgütü tarafından 11 Mart 2020 tarihinde coronavirüs (Covid-19), pandemi olarak ilan edilmiștir. Sağlık Bakanlığı (2020) verilerine göre; 4 Ocak 2021 tarihine kadar ülkemizde görülen toplam vaka sayısı 1.928 .165 olurken, toplam vefat sayısı ise 17.121 olmuştur. Her ne kadar birçok ülke ve bilim adamı bu pandemi sürecinden kurtulmak için aşı ve ilaç çalışmalarına devam ediyor olsa da coronavirüs (Covid-19) pandemi koşullarının ne zaman sona ereceği kestirilememektedir. 
Coronavirüs (Covid-19) pandemisi tüm dünyada olduğu gibi Türkiye'de de sağlık, sosyal hayat, eğitim, ekonomi başta olmak üzere tüm alanları etkilemiştir. İnsan sağlığını korumak için alınan önlemlerin adeta yeni bir hayat tarzı olarak karşımıza çıktığı, bu şekilde yaşamayı zorunlu kıldığı görülmektedir. Alınan tedbirlerin başında sokağa çıkma kısıtlamaları, seyahat kısıtlamaları, kalabalık ortamların seyreltilmesi, karantina süreçleri ve okulların kapatılması gelmektedir.

Coronavirüs (Covid-19) pandemisi tüm alanları olduğu gibi eğitimi de çok fazla etkilemiş, eğitime bakış açısı ve yorumlama biçimini değiştirmiştir (Bozkurt ve Sharma, 2020). Çoğu ülke yüzyüze eğitim öğretim faaliyetlerine ara vermek zorunda kalmıştır. Ülkemizde de 16 Mart 2020 tarihinde yüzyüze eğitime ara verilmiştir. $\mathrm{Bu}$ tarihten itibaren uzaktan eğitim yapılmaya başlanmıştır. Pandemi dönemi ile birlikte uygulamaya konulan uzaktan eğitim, bir kriz durumunda yüz yüze eğitimin geçici olarak dijital ortama aktarılmasıdır ve acil uzaktan öğretim veya acil durum uzaktan öğretim olarak adlandırılır (Akkoyunlu ve Bardakçı, 2020). Bu süreçte, ilkokul, ortaokul ve liselere yönelik 3 farklı televizyon kanalı yayına başlamıştır. Eğitim Bilişim Ağı (EBA) platformu teknik olarak desteklenerek, öğretmenlerin canlı sınıflar oluşturup ders yapabilmelerine imkân sağlanmıştır. Canlı sınıflar, eğitimin internet aracıllğıyla çevrimiçi olarak gerçekleşmesini sağlar (Kaya, 2002). Mobil uygulamalar geliştirilmiş, öğrenci ve velilerin kullanımına sunulmuştur. Yine hazırlanan içerikler online olarak öğretmen ve öğrencilerin erişimine sunulmuştur. İnternet bağlantısı ile ilgili cep telefonu operatörleri tarafından ücretsiz data hakkı tanımlanırken, Milli Eğitim Bakanlı̆̆ı başta olmak üzere çeşitli kurum ve kuruluşlardan ihtiyaç sahibi öğrencilere tablet yardımı yapılmıştır. Yine okullarda EBA destek noktaları olușturularak öğrencilerin okulun maddi imkanlarını kullanmalarının önü açılmıştır. Pandemi süreci ile başlayan uzaktan eğitim ile birlikte geleneksel eğitim anlayışı büyük bir değişikliğe uğrayarak yerini yeni nesil öğretmen, öğrenci, dokümanlara bırakmıştır (Harasim, 2000).

Eğitimin kesintiye uğramaması için tüm dünyada uzaktan eğitim yöntemleri kullanılmaktadır. Bu durumun başarılı olup olmadığını tespit etmek henüz mümkün görülmemektedir. Ancak şu bir gerçektir ki; farklı maddi imkanlara sahip öğrenciler arasında eğitsel farklar gün geçtikçe artmaktadır. Bu da pandemi sonrası öğrencilerin eşit eğitim alabilme hususunda büyük zorluklara sebep olabilecektir (Giannini ve Lewis, 2020). Çünkü pandemi süreci ile birlikte eğitime katılım ve devamın zayıf olduğu bölgelerdeki öğrenciler ile maddi imkandan yoksun öğrencilerin eğitim ile bağlantısı kopmuştur.

Uzaktan eğitimin bir anda bu denli yaygın ve temel yöntem olarak, anaokulundan üniversiteye kadar uygulanması ile öğretmen, öğrenci ve veliler, alışık olmadıkları bir sistemle karşı karşıya kalmışlardır. Bu süreç ile birlikte öğretmenlere çok daha fazla iş düşmüştür. Bir yandan kendi bilgi ve birikimini uzaktan eğitime evirirken bir yandan da öğrenci ve velilere rehberlik ederek oryantasyon faaliyetleri yapmışlardır. Ancak sosyo-ekonomik duruma bağlı olarak, dijital dünya fazla yabancı olunan bir alan olmadığından uyum problemleri çok kısa sürede atlatılmıştır.

Uzaktan eğitim faaliyetlerinin verimli olabilmesi için, uzaktan eğitim ile ilgili algılar önemli bir etmendir (Başar ve diğerleri, 2019). Olumlu yargılara sahip bireylerin, sistemin başarısının artmasında büyük öneme 
sahiptir. Literatür taraması yapıldığı zaman öğretmenlerin, öğrencilerin ve öğretim görevlilerinin uzaktan eğitime yönelik algı ve tutumları inceleyen birçok çalışmaya rastlamaktadır. Ak ve diğerleri (2021), Başar ve diğerleri (2019), Durdu ve Albayrak (2020), Gök ve Kllıç Çakmak(2020), Gökbulut (2021), Kocayiğit ve Uşun (2020), Kurnaz ve diğerleri (2020) Moçoşoğlu ve Kaya(2020), Özdoğan ve Berkant(2020) ve Türküresin (2020) bu çalışmalara en güncel örneklerdendir.

$\mathrm{Bu}$ çalışma ile öğretmenlerin uzaktan eğitim faaliyetlerine ilişkin yarar algıları belirlenmeye çalışarak bu algıların çeşitli değişkenlere göre incelemesi yapılmıştır. Bu bağlamda aşağıdaki sorulara cevap aranmıştır:

1. Öğretmenlerin uzaktan eğitimin yarar algıları ne düzeydedir?

2. Öğretmenlerin cinsiyetleri ile uzaktan eğitimin yararına ilişkin algıları arasında anlamlı bir farklılık var mıdır?

3. Öğretmenlerin öğrenim durumu ile uzaktan eğitimin yararına ilişkin algıları arasında anlamlı bir farklılık var mıdır?

4. Öğretmenlerin görev yaptığınız okul türü ile uzaktan eğitimin yararına ilişkin algıları arasında anlamlı bir farklılık var mıdır?

5. Öğretmenlerin kıdem yılı ile uzaktan eğitimin yararına ilişkin algıları arasında anlamlı bir farklılık var midır?

Pandemi süreci ile uzaktan eğitimin yeni norm haline gelmesi ve bu sürecin en önemli yürütücüsü olan öğretmenlerin yarar algılarının belirlenmesi sürecin verimliliği ve geliştirilmesi açısından büyük önem taşımaktadır. Bununla birlikte alan yazına katkı sağlaması açısından bu araştırma önemli görülmektedir.

\section{YÖNTEM}

Araştırma probleminin çözümünde kullanılacak yöntem; araştırmanın amacına ve araştırma probleminin doğasına göre belirlenmelidir (Creswell, 2014). Öğretmenlerin uzaktan eğitim faaliyetlerine ilişkin yarar algılarını belirlenmeyi amaçlayan bu çalışma, nicel araştırma yöntemi olan tarama modeli ile yapılmış kesitsel bir araştırmadır. Geçmişte olmuş ya da halen devam eden bir durum, birey ya da nesneyi var olduğu şekliyle kendi şartları içerisinde ve olduğu gibi tespit etmek için tarama modeli kullanılır (Karasar, 1995). Tarama araştırmasıyla çalışma grubunun amaçlanan özelliklerini tespit edebilmek amacıyla veri toplanması gerçekleştirilir (Büyüköztürk ve diğerleri, 2008).

\section{Çalışma Grubu}

Araştırmanın çalışma grubu belirlenirken amaçlı örneklem yöntemi kullanılmıştır. Bu yöntemde ana olgu hakkında bilgi edinmek için katılımcıları ve araştırma mekânları amaca uygun bir şekilde seçilir (Creswell, 2017). Araştırma çalışma gurubunun belli şartları sağlaması dikkate alınarak belirlenip seçilmiştir (Patton, 2014). Bu çalışmada katılımıcıların gönüllü ve uzaktan eğitim faaliyetlerini yürütmeleri şartları gözönünde 
bulundurulmuştur. Araştırmanın çalışma grubunu 2020-2021 eğitim öğretim yılında Sinop ili Boyabat ilçesinde uzaktan eğitim faaliyetlerini yürüten 240 öğretmen oluşturmaktadır. Öğretmenlerin demografik bilgileri Tablo 1 'de gösterilmiştir.

\section{Tablo 1}

Katılımclların demografik bilgileri

\begin{tabular}{llcc}
\hline & Değişkenler & Frekans(n) & Yüzde (\%) \\
\hline \multirow{2}{*}{ Cinsiyet } & Kadın & 139 & 57.4 \\
& Erkek & 103 & 42.6 \\
Öğrenim Durumu & Lisans & 228 & 94.2 \\
& Yüksek Lisans & 14 & 5.8 \\
& Anaokulu & 13 & 5.4 \\
Görev Yapılan Okul Türü & İlkokul & 81 & 33.5 \\
& Ortaokul & 81 & 33.5 \\
& Lise & 67 & 27.6 \\
Kıdem Yılı & $\mathbf{0 - 1 0}$ yıl & 129 & 53.3 \\
& $\mathbf{1 1 - 2 0}$ yıl & 73 & 30.2 \\
& $\mathbf{2 1 - 3 0}$ yıl & 33 & 13.6 \\
\hline
\end{tabular}

Tablo 1'e göre; katılımcıların cinsiyetlerine bakıldığında; 139 kadın (\%57.4), 103 erkek (\%42.6) şeklinde görülmektedir. Öğrenim durumları incelendiğinde 228 lisans (\%94.2) ve 14 yüksek lisans (\%5.8) mezunu öğretmen görülmektedir. Görev yapılan okul türüne göre sinıflandığında; 13 anaokulu (\%5.4), 81 ilkokul (\%33.5), 81 ortaokul (\%33.5)ve 67 lise (\%27.6) düzeyinde görev yapan katılımcı bulunmaktadır. Kıdem yılı incelendiğinde ise; 129 katılımcının (\%53.3) 0-10 yll, 73 katılımcının (\%30.2) 11-20 yll, 33 katılımcının (\%13.6) ve 7 katılımcının (\%2.9) 31 yıl ve üstü görev süreleri bulunmaktadır. Bunlara göre kadın, lisans mezunu, ortaokul veya ilkokulda görev yapan, 0-10 yıl arası hizmet süresi bulunan katılımcıların çoğunlukta olduğu görülmektedir.

\section{Verilerin Toplanması}

Amaca yönelik gerçekleştirilen literatür taraması ile problem durumuna yönelik yapılan çalışmalar toplanmıştır. $\mathrm{Bu}$ tarama neticesinde iki bölümden oluşan ölçme aracı geliştirilmiştir. Birinci bölümde katılımcların demografik bilgileri yer alırken, ikinci bölümde Yıldız (2015) tarafından geliştirilen uzaktan eğitime yönelik yarar algısı ölçeği bulunmaktadır. Birinci kısımda katılımcılardan demografik bilgi olarak; cinsiyet, öğrenim durumu, görev yapılan okul türü ve kıdem yılı istenmiștir. İkinci kısımda yer alan uzaktan eğitime yönelik yarar algısı ölçeği 16 maddeden oluşmaktadır. Bu maddelerden 1.,2.,3.,4.,5.,6.,7.,9. ve 10.maddeler öğrenme ürünlerinin etkililiğini, 11., 12., ve 13. maddeler öğrenme yaşantılarının zenginliğini, 8., 14., 15. ve 16. maddeler de sistemin ekonomikliği faktörlerini içermektedir (Yıldız,2015). Anket değerlendirilmesi beşli dereceleme ölçeği ile yapılmıştır. Katılımcılar, ankette yer alan sorulara "Kesinlikle Katılmıyorum”, "Katılmıyorum”, “Kararsızım”, “Katılıyorum”, “Kesinlikle Katılıyorum” seçeneklerinden birini 
tercih ederek değerlendirme yapmışlardır. Veri toplama Coronavirüs (Covid-19) pandemisinin şartları göz önünde bulundurularak, çevrim içi ortamda Google Forms aracılığıyla gönüllülük ilkesi çerçevesinde gerçekleştirilmiștir. Elde edilen verilerin normallik testi yapılmış ve yapılan Kolmogorov-Smirnov normallik testi sonuçları Tablo 2'de gösterilmiştir.

\section{Tablo 2}

Uzaktan eğitime yönelik yarar algısı ölçeğinin normal dağılım sonuçları

\begin{tabular}{cccc}
\hline & \multicolumn{3}{c}{ Kolmogorov-Smirnov } \\
\hline \multirow{2}{*}{ Yarar AlgıSı } & İstatistik & df & Sig. \\
& .048 & 242 & .200 \\
\hline
\end{tabular}

Tablo 2' de görülen; Kolmogorov-Smirnov normallik testi sonuçlarına göre; $D(242)=0.048$ ve p=0.200>0.05 olarak hesaplanmıştır. Buna göre elde edilen verilerin normal dağılım gösterdiği kabul edilmiştir.

Uzaktan eğitime yönelik yarar algısı ölçeğinin güvenirliliği için yapılan analiz sonucunda ölçeğin güvenirlik Cronbach’s Alpha iç tutarlılık katsayısı .946 çıkmıştır. Bu sonuç .80'den büyük olduğu için testin güvenilir olduğu kabul edilmiştir (Tavşancll,2006).

\section{Verilerin Analizi}

Araştırmanın kaynağı olan öğretmenlerden toplanan veriler, SPSS 24 programına aktarılarak analiz edilmiştir. Verilerin normallik varsayımları Kolmogorov-Smirnov testi ile, güvenirliliği Cronbach’s Alpha ile test edilmiştir. Veriler, frekans, yüzde, ortalama, standart sapma, $\mathrm{t}$ testi ve Anova testleri uygulanarak analiz edilmiş ve yorumlama yapılmıştır.

\section{BULGULAR ve YORUM}

$\mathrm{Bu}$ bölümde araştırma soruları doğrultusunda elde edilen verilerin analizleri yapılarak ortaya çıkan bulgular sunulmuştur.

Öğretmenlerin uzaktan eğitim faaliyetlerine ilişkin yarar algıları ölçeğine verdikleri yanıtlar Tablo 3`de aktarılmıștır. 


\section{Tablo 3.}

Öğretmenlerin uzaktan eğitim faaliyetlerine ilişkin yarar algıları ölçeği soru maddelerine ait tanımlayıcı istatistikler

\section{(n)}

\begin{tabular}{|c|c|c|c|c|c|c|c|c|c|c|c|c|}
\hline Bana göre uzaktan eğitim; & $\mathbf{n}$ & $\%$ & $\mathbf{n}$ & $\%$ & $\mathbf{n}$ & $\%$ & $\mathbf{n}$ & $\%$ & $\mathbf{n}$ & $\%$ & & \\
\hline Etkili öğrenmeler sağlar. & 41 & 16.9 & 95 & 39.3 & 37 & 15.3 & 65 & 26.9 & 4 & 1.7 & 2.57 & 1.11 \\
\hline Bağımsız öğrenme becerilerini geliştirir. & 39 & 16.1 & 63 & 26 & 42 & 17.4 & 85 & 35.1 & 13 & 5.4 & 2.88 & 1.21 \\
\hline Çok yönlü öğrenme olanakları sunar. & 39 & 16.1 & 77 & 31.8 & 39 & 16.1 & 76 & 31.4 & 11 & 4.5 & 2.76 & 1.19 \\
\hline Eleştirel düşünme becerilerini geliştirir. & 39 & 16.1 & 90 & 37.2 & 64 & 26.4 & 43 & 17.8 & 6 & 2.5 & 2.53 & 1.04 \\
\hline Öğrenmeye motive eder. & 45 & 18.6 & 104 & 43 & 50 & 20.7 & 37 & 15.3 & 6 & 2.5 & 2.40 & 1.03 \\
\hline Katılımı artırır. & 73 & 30.2 & 113 & 46.7 & 31 & 12.8 & 19 & 7.9 & 6 & 2.5 & 2.06 & 0.98 \\
\hline Yeni ürünler ortaya koyma becerilerini geliștirir. & 46 & 19 & 102 & 42.1 & 49 & 20.2 & 40 & 16.5 & 5 & 2.1 & 2.40 & 1.04 \\
\hline Zamandan tasarruf sağlar. & 45 & 18.6 & 62 & 25.6 & 28 & 11.6 & 75 & 31 & 32 & 13 & 2.95 & 1.36 \\
\hline Tartışmaları zenginleştirir. & 50 & 20.7 & 98 & 40.5 & 50 & 20.7 & 37 & 15.3 & 7 & 2.9 & 2.39 & 1.07 \\
\hline Daha çok öğrenciye ulaşmayı sağlar. & 96 & 39.7 & 99 & 40.9 & 24 & 9.9 & 15 & 6.2 & 8 & 3.3 & 1.93 & 1.02 \\
\hline Bireysel farklılıklara hizmet etmeyi kolaylaştırır. & 69 & 28.5 & 98 & 40.5 & 42 & 17.4 & 24 & 9.9 & 9 & 3.7 & 2.20 & 1.07 \\
\hline Daha fazla öğretim materyali kullanmayı sağlar. & 57 & 23.6 & 80 & 33.1 & 41 & 16.9 & 45 & 18.6 & 19 & 7.9 & 2.54 & 1.25 \\
\hline Değerlendirme için veri kaynaklarını zenginleștirir. & 56 & 23.1 & 87 & 36 & 35 & 14.5 & 50 & 20.7 & 14 & 5.8 & 2.50 & 1.22 \\
\hline Öğreticiye zaman kazandırır. & 53 & 21.9 & 72 & 29.8 & 35 & 14.5 & 61 & 25.2 & 21 & 8.7 & 2.69 & 1.30 \\
\hline Mekan esnekliği sağlar. & 34 & 14 & 40 & 16.5 & 28 & 11.6 & 89 & 36.8 & 51 & 21 & 3.34 & 1.35 \\
\hline Sınıf yönetimini kolaylaştırır. & 64 & 26.4 & 75 & 31 & 39 & 16.1 & 38 & 15.7 & 26 & 11 & 2.53 & 1.32 \\
\hline
\end{tabular}

Tablo 3'e göre; öğretmenlerin uzaktan eğitim faaliyetlerine ilişkin yarar algıları ile ilgili ölçeğin analiz sonuçları incelendiğinde; cevaplar ortalama aralığı, 1(Kesinlikle Katılmıyorum) ile 5 (Kesinlikle Katılıyorum) arasında değerlendirilmiş olup ortalama değer 3'tür. Parametrik testin ortalaması ise 2.54 'dür. Sorulara verilen 
cevapların ortalamalarına bakıldığı zaman; "Mekan esnekliği sağlar." maddesi ( $x=3.34$ ) ortalama ile en yüksek ortalamaya sahiptir. Bu maddeyi "Zamandan tasarruf sağlar." maddesi (x=2.95) ve "Bağımsız öğrenme becerilerini geliştirir." maddesi ( $\mathrm{x}=2.88$ ) takip etmektedir. "Daha çok öğrenciye ulaşmayı sağlar." maddesinin ise $(\mathrm{x}=1.93)$ ortalama ile en küçük ortalamaya sahip olduğu görülmektedir. Bu maddeyi "Katılımı artırır." maddesi $(\mathrm{x}=2.06)$ ve "Bireysel farklıllklara hizmet etmeyi kolaylaştırır." maddesi $(\mathrm{x}=2.20)$ takip etmektedir. "Mekan esnekliği sağlar.", "Zamandan tasarruf sağlar." ve "Bağımsız öğrenme becerilerini geliştirir." maddelerinde "Katılıyorum" cevabı ağırlıklı iken, kalan 13 maddenin tamamında "Katılmıyorum" cevabı en çok tercih edilen seçenek olmuştur.

Anket maddelerin içerdikleri faktörlere göre incelendiğinde ise; öğrenme ürünlerinin etkililiğini faktörünü içeren maddeler ( 1.,2.,3.,4.,5.,6.,7.,9., 10. maddeler) arasında "Bağımsız öğrenme becerilerini geliştirir." maddesi ( $\mathrm{x}=2.88$ ) ortalama ile en yüksek ortalamaya sahipken, "Daha çok öğrenciye ulaşmayı sağlar.” (x=1.93) ortalama ile en küçük ortalamaya sahiptir. Öğrenme yaşantılarının zenginliğini faktörünü içeren maddeler ( 11.,12. ve 13. maddeler) arasında "Daha fazla öğretim materyali kullanmayı sağlar.” maddesi ( $x=2.54)$ ortalama ile en yüksek ortalamaya sahip olduğu görülürken, "Bireysel farklılıklara hizmet etmeyi kolaylaştırır." ( $\mathrm{x}=2.20)$ maddesi ise ortalamanın en küçük olduğu madde olarak görülmektedir. Sistemin ekonomikliği faktörünü içeren maddeler ( 8., 14., 15. ve 16.. maddeler) arasında "Mekan esnekliği sağlar." maddesi ( $\mathrm{x}=3.34$ ) ortalama ile en yüksek ortalamaya sahip olduğu görülürken, "Sınıf yönetimini kolaylaştırır." (x=2.53) maddesi ise ortalamanın en küçük olduğu madde olarak görülmektedir.

Anket maddelerin içerdikleri faktörlere göre ortalamalarına bakıldı̆̆ı zaman; sistemin ekonomikliği faktörünü içeren maddelerin ( 8., 14., 15. ve 16.. maddeler) $X=2.88$, öğrenme ürünlerinin etkililiğini faktörünü içeren maddelerin ( 1.,2.,3.,4.,5.,6.,7.,9., 10. maddeler) $X=2.44$, öğrenme yaşantılarının zenginliğini faktörünü içeren maddelerin (11.,12. ve 13. maddeler) $\mathrm{X}=2.41$ olduğu görülmektedir.

Öğretmenlerin uzaktan eğitim faaliyetlerine ilişkin yarar algıları ölçeğine verdikleri yanıtların faktör ortalamaları sonuçları Tablo 4'de aktarılmıştır.

\section{Tablo 4}

Öğretmenlerin uzaktan eğitim faaliyetlerine ilişkin yarar algıları ölçeği faktör analizi sonuçları

\begin{tabular}{lcc}
\hline Faktörler & $\mathrm{X}$ & $\mathrm{SS}$ \\
\hline Öğrenme Ürünlerinin Etkililiğini & 2.44 & 0.87 \\
Öğrenme Yaşantılarının Zenginliğini & 2.41 & 1.03 \\
Sistemin Ekonomikliği & 2.88 & 1.08 \\
Toplam & 2.54 & 0.87 \\
\hline
\end{tabular}

Tablo 4'e göre; anket maddelerin içerdikleri faktörlere göre ortalamalarına bakıldığı zaman; sistemin ekonomikliği faktörünü içeren maddelerin ( $8 ., 14 ., 15$. ve 16.. maddeler) $X=2.88$, öğrenme ürünlerinin etkililiğini faktörünü içeren maddelerin ( 1.,2.,3.,4.,5.,6.,7.,9., 10. maddeler)X= 2.44 öğrenme yaşantılarının zenginliğini faktörünü içeren maddelerin (11.,12. ve 13. maddeler) X=2.41 olduğu görülmektedir. 
Öğretmenlerin uzaktan eğitim yarar algılarının cinsiyet faktörü bağlamında incelenmesine ait veriler

Tablo 5’ de gösterilmiştir.

\section{Tablo 5}

Öğretmenlerin uzaktan eğitim faaliyetlerine ilişkin yarar algılarının cinsiyet faktörü bağlamında incelenmesi

\begin{tabular}{cccccccc}
\hline Cinsiyet & N & X & SS & Sd & t & p & Anlamlılı Düzeyi \\
\hline Kadın & 139 & 2.65 & .84566 & 240 & 2.312 & .428 & p $>0.05$ \\
Erkek & 103 & 2.39 & .88032 & & & & \\
\hline
\end{tabular}

Tablo 5'e göre; kadın öğretmenlerin yarar algı ortalaması, erkek öğretmenlerin ortalamasından yüksektir (2.65>2.39). Öğretmenlerin cinsiyeti ile uzaktan eğitim faaliyetlerine ilişkin yarar algıları arasında $(\mathrm{t}=2.312, \mathrm{p}=0.428>.05)$ anlamlı bir farklılık yoktur.

Öğretmenlerin uzaktan eğitim yarar algılarının öğrenim durumu faktörü bağlamında incelenmesine ait veriler Tablo 6’ da gösterilmiştir.

\section{Tablo 6}

Öğretmenlerin uzaktan eğitim faaliyetlerine ilişkin yarar algılarının öğrenim durumu faktörü bağlamında incelenmesi

\begin{tabular}{cccccccc}
\hline Öğrenim Durumu & $\mathbf{N}$ & $\mathbf{X}$ & SS & Sd & $\mathbf{t}$ & $\mathbf{p}$ & Anlamlılık Düzeyi \\
\hline Lisans & 228 & 2.53 & .87515 & 240 & -.445 & .702 & $\mathrm{p}>0.05$ \\
Yüksek Lisans & 14 & 2.64 & .76877 & & & & \\
\hline
\end{tabular}

Tablo 6’ya göre; yüksek lisans mezunu öğretmenlerin yarar algı ortalaması, lisans mezunu öğretmenlerin ortalamasından yüksektir (2.64>2.53). Öğretmenlerin öğrenim durumu ile uzaktan eğitim faaliyetlerine ilişkin yarar algıları arasında ( $\mathrm{t}=-.445, \mathrm{p}=.702>.05)$ anlamlı bir farklılık bulunmamaktadır.

Öğretmenlerin uzaktan eğitim yarar algılarının görev yaptıkları okul türü faktörü bağlamında incelenmesine ait veriler Tablo 7’ de gösterilmiştir.

\section{Tablo 7}

Öğretmenlerin uzaktan eğitim faaliyetlerine ilişkin yarar algılarının görev yapılan okul türü faktörü bağlamında incelenmesi

\begin{tabular}{ccccccc}
\hline Boyut & Okul Türü & N & X & SS & F & p \\
\hline & Anaokulu & 13 & 3.49 & 1.18626 & 6.766 & .000 \\
İ̈rrev Yapllan Okul Türü & Irkokul & 81 & 2.37 & .74346 & & \\
& Ortaokul & 81 & 2.51 & .82520 & & \\
& Lise & 67 & 2.59 & .88618 & & \\
& Toplam & 242 & 3.49 & .86828 & & \\
\hline
\end{tabular}

Tablo 7’ye göre; öğretmenlerin görev yaptıkları okul türü ile uzaktan eğitim faaliyetlerine ilişkin yarar algıları arasındaki ilişkiler ait ortalamalara bakıldığında; en yüksek ortalamaya $(X=3.49)$ anaokulunda görev 
yapan öğretmenler sahiptir. Bunu lisede $(X=2.59)$ ve ortaokulda $(X=2.37)$ görev yapan öğretmenler takip etmektedir. En az ortalamaya ise 2.37 ile ilkokulda görev yapan öğretmenler sahiptir.

Öğretmenlerin uzaktan eğitim faaliyetlerine ilişkin yarar algılarının görev yaptıkları okul türüne göre anlamlı bir şekilde farklılaşıp farklılaşmadığını belirlenmek için tek yönlü varyans analizi yapılmıştır. Yapılan ANOVA testi sonucuna göre $(\mathrm{p}=.000<.05)$ öğretmenlerin görev yaptıkları okul türü faktörüne göre uzaktan eğitim faaliyetlerine ilişkin yarar algıları arasında istatistik olarak anlamlı bir farklılık hesaplanmıştır. Bu farklılığın yönünü bulmak için yapılan Post-Hoc analizi sonuçlarına göre anaokulunda görev yapan öğretmenlerin uzaktan eğitim faaliyetlerine ilişkin yarar algıları diğer kademelerde görev yapan öğretmenler arasında anlamlı bir farklılık belirlenmiștir.

Öğretmenlerin uzaktan eğitim yarar algılarının kıdem yılı faktörü bağlamında incelenmesine ait veriler Tablo 8' de gösterilmiştir.

\section{Tablo 8}

Öğretmenlerin uzaktan eğitim faaliyetlerine ilişkin yarar algılarının kıdem yılı faktörü bağlamında incelenmesi

\begin{tabular}{lcccccc}
\hline Boyut & Kıdem Yılı & $\mathbf{N}$ & $\mathbf{X}$ & SS & F & p \\
\hline \multirow{4}{*}{ Kıdem Yılı } & $0-10$ yll & 129 & 2.55 & .87446 & 1.199 & .331 \\
& $11-20$ yll & 73 & 2.55 & .87554 & & \\
& $21-30$ yll & 33 & 2.60 & .83412 & & \\
& 31 yll ve üstü & 7 & 1.93 & .77979 & & \\
\hline
\end{tabular}

Tablo 8'e göre; öğretmenlerin kıdem yılları ile uzaktan eğitim faaliyetlerine ilişkin yarar algıları arasındaki ilişkiler ait ortalamalara bakıldığında; en yüksek ortalamaya (X=2.60) 21-30 yıl kıdeme sahip öğretmenler sahiptir. Bunu 0-10 yıl (X=2.55) ve 11-20 yıl (X=2.55) kıdeme sahip öğretmenler takip etmektedir. En az ortalama ise 1.93 ile 31 yıl ve üstü kıdeme sahip öğretmenlerde görülmüştür.

Öğretmenlerin uzaktan eğitim faaliyetlerine ilişkin yarar algılarının kıdem yıllarına göre anlamlı bir şekilde farklılaşıp farklılaşmadığını belirlenmek için tek yönlü varyans analizi yapılmıştır. Yapılan ANOVA testi sonucuna göre $(\mathrm{p}=0.331>0.05)$ kıdem yılı faktörüne göre uzaktan eğitim faaliyetlerine ilişkin yarar algıları arasında istatistik olarak anlamlı bir farklılık hesaplanmamıştır.

\section{TARTIŞMA, SONUÇ VE ÖNERİLER}

Öğretmenlerin uzaktan eğitimin yarar algılarını ve bu algılarının çeşitli faktörlere göre değerlendirilmesi yapılmıştır. Uzaktan eğitimin yarar algıları anket sonuçlarının parametrik ortalaması 2.54'dür. Bu da öğretmenlerin uzaktan eğitimin yararları ile algılarının kararsıza yakın olduğunu göstermektedir. Ülkü (2018) ve Moçoşoğlu ve Kaya'nın (2020) araştırmaları da bu sonucu desteklemektedir. Uzaktan eğitimin mekan esnekliği sağlaması, zamandan tasarruf sağlaması, bağımsız öğrenme becerilerini geliştirmesi, çok yönlü öğrenme olanakları sunması, öğreticiye zaman kazandırması ve etkili öğrenmeler 
sağlaması konularında öğretmenler olumlu düşünceye sahip oldukları ve uzaktan eğitimin bu yönlerinin faydalı olduğuna katıldıkları görülmektedir. Fidan(2020)'ın yaptığı araştırma sonucuna göre; öğretmenlerin çoğunluğunun uzaktan eğitimin akademik olarak olumlu görüş sahibi olduklarını belirtmiştir. Russel (1999) yaptığı çalışma eğitim teknolojileriyle uzaktan eğitimin iyi yapılandırılmasıyla yüz yüze eğitim ve uzaktan eğitim arasında bir farkın olmayacağı sonucuna ulaşmıştır. Eğitsel etkileşim kaliteli ve yüksek düzeyde sağlandığı zaman anlamlı öğrenmeler gerçekleşir (Anderson, 2003). Öğretmenlerin uzaktan eğitimin daha fazla öğretim materyali kullanmayı sağlaması konusunda karasız kalmışlardır. Başaran ve arkadaşlarının (2020) yaptıkları araştırmada zengin öğrenme materyallerinin hazırlanması ve ders içeriklerinin uzaktan eğitime uygun hale getirilmesi ile uzaktan eğitimin öğrencinin bireysel öğrenmesine imkan vereceğini belirtmişlerdir. Materyallerin zenginleștirilmesi bireysel farklılıkları ortadan kaldırılır (Kettanurak, Ramamurth ve Haseman, 2001). Öğretmenlerin uzaktan eğitimin; sınıf yönetimini kolaylaştırdığına dair olumsuz algılarını, Fidan (2020)'ın yaptığı araştırma sonucu da desteklemektedir. Bu araștırmada da öğretmenler sınıf yönetimi bağlamında olumsuz görüşler belirtmişlerdir. Uzaktan eğitimin eleştirel düşünme becerilerini geliştirdiği, değerlendirme için veri kaynaklarını zenginleştirdiği, yeni ürünler ortaya koyma becerilerini geliştirdiği, tartışmaları zenginleştirdiği, bireysel farklılıklara hizmet etmeyi kolaylaştırdığı, katılımı artırdığı ve daha çok öğrenciye ulaşmayı sağladığı, maddelerinin yararına karşı olumsuz algıya sahip oldukları ve bu yararlarına katılmadıkları sonucuna ulaşılmıştır. Arık (2020)'ın çalışma sonucuna göre, Milli Eğitim Bakanlığı tarafından yapılan tüm çalışmalara rağmen, hem imkan hem şartlardan dolayı uzaktan eğitime katılamayan öğrencilerin olabileceğini belirtmiştir. Karadağ ve Yücel (2020) araştırma sonuçlarına göre; öğrencilerin \%23'ünün uzaktan eğitimlerini devam ettiremediklerini söylediklerini belirtmişlerdir. Fidan(2020)'ın araştırma sonuçlarına göre; öğretmenlerin uzaktan eğitimde erişim sıkıntısını en olumsuz yön olarak belirtmişlerdir. Baek ve diğerleri (2018) çalışması da bu sonucu desteklemektedir. Yine, öğretmenler uzaktan eğitimin öğrenmeye motive ettiğine karşı olumsuz algılarının olduğu ortaya çıkmıştır. Yapılan bir araştırmada çevrimiçi eğitimin en önemli belirleyicilerinden birinin içsel motivasyon olduğu sonucuna ulaşmıștır(Fırat, Kılınç ve Yüzer, 2018). Ancak araştırma sonucuna göre öğretmenlerin uzaktan eğitimin öğrenmeye motive etmesi konusunda olumsuz görüş belirtmişlerdir. Anket maddelerinin içerdiği faktörlere göre değerlendirildiğinde ise; öğretmenler uzaktan eğitimi ekonomik olduğunu katılırken, öğrenme ürünlerinin etkililiğini ve öğrenme yaşantılarının zenginliğini artırdığına katılmadıkları görülmüştür.

Öğretmenlerin uzaktan eğitim algıların cinsiyet faktörüne göre anlamlı bir farklılık göstermediği ancak kadın öğretmenlerin erkek öğretmenlerden daha olumlu bir algılarının olduğu sonucuna ulaşılmıştır. Bu sonucu destekleyen birçok çalışma literatürde mevcuttur. Bayram ve diğerleri (2019), Kocayiğit ve Uşun (2020), Kurnaz ve diğerleri(2021), Moçoşoğlu ve Kaya (2020), yaptıkları çalışmalar bunlardan bazılarıdır.

Öğretmenlerin uzaktan eğitim algıların öğrenim durumu faktörüne bağlı olarak anlamlı bir farklılık göstermediği fakat yüksek lisans mezunu öğretmenlerin lisans mezunu öğretmenlerden daha olumlu bir algılarının olduğu sonucuna ulaşılmıştır. Kocayiğit ve Uşun (2020), Moçoşoğlu ve Kaya (2020) araştırma 
bulguları ile bu sonucu desteklemektedir.Ancak Ülkü'nün (2018) çalışma sonuçlarına göre önlisans mezunlarına göre yüksek lisans mezunları lehinde anlamlı bir farklılık görülmüştür.

Öğretmenlerin uzaktan eğitim alglların görev yapılan okul türüne göre anlamlı bir farklılık gösterdiği, anaokulunda görev yapan öğretmenlerin diğer okul türlerinde görev yapan öğretmenlerden daha olumlu bir algılarının olduğu ve anlamlı bir şekilde farklılaştığı görülmüştür. Moçoşoğlu ve Kaya (2020) ve Kurnaz ve diğerleri (2021) araştırmaları ile bu sonucu desteklemektedir.

Öğretmenlerin uzaktan eğitim algıların kıdem yılı faktörüne göre anlamlı bir farklılık göstermediği görülmüştür. Kocayiğit ve Uşun (2020), Kurnaz ve diğerleri(2021) ve Ülkü (2018) araştırma bulguları ile bu sonucu desteklemektedir. Ancak 21-30 yıl kıdeme sahip öğretmenlerin daha olumlu bir algılarının olduğu sonucuna ulaşılmıştır. Bu sonuç ise literatürdeki bazı çalışmalar ile çelişmektedir. Ağır (2007), Okçu ve Ağır (2006 ve Moçoşoğlu ve Kaya'nın (2020) araştırmalarında kıdem yılı düşük öğretmenlerin uzaktan eğitime yönelik tutumları daha yüksek çıkmıştır.

Bu sonuçlar ışığında sistemin daha verimli hale gelmesi için öğretmenlerin yarar algılarının yüksek düzeyde olması gerekir. Bunun için bu araştırma nitel araştırma yöntemi ile tekrarlanarak öğretmenlerin uzaktan eğitimin yarar algılarının düşük olmasının sebepleri araştırılabilir. Elde edilecek verilere göre uzaktan eğitim süreçleri ile ilgili düzenlemeler yapılabilir. Bununla birlikte öğretmenlere uzaktan eğitimde sınıf yönetimi başta olmak üzere pedagojik alanda hizmetiçi eğitimler verilebilir.

\section{KAYNAKÇA}

Ağır, F. (2007). Özel okullarda ve devlet okullarında çalışan ilköğretim öğretmenlerinin uzaktan eğitime karşı tutumlarının belirlenmesi [Yayımlanmamış yüksek lisans tezi]. Balıkesir Üniversitesi, Fen Bilimleri Enstitüsü, Balıkesir.

Ak, Ş., Gökdaş, İ., Öksüz, C. ve Torun, F . (2021). Uzaktan eğitimde eğiticilerin eğitimi: Uzaktan eğitime yönelik öz yeterlik ve yarar algısına etkisi . Açıöğretim Uygulamaları ve Araştırmaları Dergisi , 7 (1) , 24-44 .

Akkoyunlu, B. ve Bardakcı S. (2020). Pandemi döneminde uzaktan eğitim. Yüksek Öğretim Kalite Kurulu. https://portal.yokak.gov.tr/makale/pandemi-doneminde-uzaktan-egitim

Alkan, C. (1997). Eğitim teknolojisi. Ankara :Anı Yayıncllık.

Arık, B. M. (2020). Türkiye'de koronavirüsün eğitime etkileri-I. Eğitim Reformu Girişimi. https://www.egitimreformugirisimi.org/turkiyede-koronavirusun-egitime-etkileri-i

Baek, J. H., Jones, E., Bulger, S. ve Taliaferro, A. (2018). Physical education teacher perceptions of technologyrelated learning experiences: A qualitative investigation. Journal of Teaching in Physical Education, 37(2), 175-185. 
Başar, M., Arslan, S., Günsel, E. ve Akpınar, M . (2019). Öğretmen adaylarının uzaktan eğitim algısı . Journal of Multidisciplinary Studies in Education, 3 (2) , 14-22.

Başaran, M., Doğan, E., Karaoğlu, E. ve Şahin, E. (2020). Koronavirüs (Covid-19) Pandemi sürecinin getirisi olan uzaktan eğitimin etkililiği üzerine bir çalışma. Academia Eğitim Araştırmaları Dergisi, 5 (2) , 368-397.

Bayram, M., Peker, A. T., Aka, S. T. ve Vural, M. (2019). Üniversite öğrencilerinin uzaktan eğitim dersine karşı tutumlarının incelenmesi. Gaziantep Üniversitesi Spor Bilimleri Dergisi, 4(3), 330-345. https://doi.org/10.31680/gaunjss.586113

Bozkurt, A. ve Sharma, R. C. (2020). Emergency remote teaching in a time of global crisis due to CoronaVirus pandemic. Asian Journal of Distance Education, 15(1), i-vi.

Büyüköztürk, Ş., Çakmak, E. K., Akgün, Ö. E., Karadeniz, Ș. ve Demirel, F. (2008). Bilimsel araştırma yöntemleri. Pegem Akademi.

Creswell, J. W. (2014). Araştırma deseni: Nitel, nicel ve karma yöntem yaklaşımları (S. B. Demir, çev). Eğiten Kitap

Creswell, J. W. (2017). Eğitim araştırmaları. EDAM Eğitim Danışmanlığı ve Araştırmaları Merkezi.

Durdu, E. ve Albayrak, M. (2020). Öğrencilerin uzaktan öğrenmeye ilişkin algı ve tutumlarının değerlendirilmesi. International Journal of Social Sciences and Education Research, 6 (2), 252-268. https://doi.org/10.24289/ijsser.728184

Fidan, M. (2020). Covid-19 Belirsizliğinde eğitim: İlkokulda zorunlu uzaktan eğitime ilişkin öğretmen görüşleri. Ușak Üniversitesi Eğitim Araştırmaları Dergisi, 6 (2), 24-43.

Firat, M., Kılınç, H. ve Yüzer, T. V. (2018). Level of intrinsic motivation of distance education students in elearning environments. Journal of Computer Assisted Learning, 34 (1), 63-70.

Giannini, S. ve Lewis, S. G. (2020). Three ways to plan for equity during the coronavirus school closures. https://gemreportunesco.wordpress.com/2020/03/25/three-ways-to-plan-for-equityduring-the-coronavirus-school-closures

Gök, B. ve Kılıç Çakmak, E. (2020). Uzaktan eğitimde ders veren öğretim elemanlarının uzaktan eğitim algısı . Kastamonu Eğitim Dergisi, 28 (5), 1915-1931 . https://doi.org/10.24106/kefdergi.3914

Gökbulut, B . (2021). Uzaktan eğitim öğrencilerinin bakış açısıyla uzaktan eğitim ve mobil öğrenme. Eğitim Teknolojisi Kuram ve Uygulama, 11 (1) , 160-177. https://doi.org/10.17943/etku.797164

Harasim, L. (2000). Shift happens: Online education as a new paradigm in learning. The Internet And Higher Education, 3(1-2), 41-61.

İşman, A. (2008). Uzaktan eğitim. Pegem Akademi. 
Karadağ, E. ve Yücel, C. (2020). Yeni tip Koronavirüs pandemisi döneminde üniversitelerde uzaktan eğitim: Lisans öğrencileri kapsamında bir değerlendirme çalışması. Yükseköğretim Dergisi, 10(2), 181-192.

Karasar, N. (1995). Bilimsel araştirma yöntemi: Kavramlar, ilkeler, teknikler. Anı Yayıncılık.

Kaya, Z. (2002). Uzaktan eğitim.Pegem A. Yayıncılık.

Kettanurak, V. N., Ramamurthy, K. ve Haseman, W. D. (2001). User attitude as a mediator of learning performance improvement in an interactive multimedia environment: An empirical investigation of the degree of interactivity and learning styles. International Journal of Human-Computer Studies, 54(4), 541583.

Kırık, A. (2014). Uzaktan eğitimin tarihsel gelişimi ve Türkiye'deki durumu. Marmara İletişim Dergisi, (21), 7394.

Kocayiğit, A. ve Salih, U. (2020). Milli eğitim bakanlığına bağlı okullarda görev yapan öğretmenlerin uzaktan eğitime yönelik tutumları (Burdur ili örneği). Avrasya Uluslararası Araştırmalar Dergisi, 8(23), 285-299.

Kurnaz, A., Kaynar, H., Barışık, C. Ş. ve Doğrukök, B. (2020). Öğretmenlerin uzaktan eğitime ilişkin görüşleri. Milli Eğitim Dergisi, 49(1), 293-322.

Moçoşoğlu, B. ve Kaya, A. (2020). Koronavirüs hastalığı (Covid-19) sebebiyle uygulanan uzaktan eğitime yönelik öğretmen tutumlarının incelenmesi. Kahramanmaraş Sütçü İmam Üniversitesi Eğitim Dergisi, 2(1), 15-43.

Okçu, A. ve Ağır, F. (2006). İlköğretimde çalışan öğretmenlerin internet kullanımına karşı tutumlarının belirlenmesi. 7. Fen Bilimleri ve Matematik Eğitimi Kongresi Özetler Kitabı, 288, 7-9.

Özdoğan, A. ve Berkant, H . (2020). Covid-19 pandemi dönemindeki uzaktan eğitime ilişkin paydaş görüşlerinin incelenmesi. Milli Eğitim Dergisi, Salgın Sürecinde Türkiye'de ve Dünyada Eğitim, 13-43. https://doi.org/ 10.37669/milliegitim.788118

Patton, M. Q. (2014). Nitel araștırma yöntemleri. Pegem Akademi.

Sağlık Bakanlığı. (2020). Türkiye günlük koronavirüs tablosu. https://Covid19.saglik.gov.tr/web

Tavşancıl, E. (2006). Tutumların ölçülmesi ve SPSS ile veri analizi. Nobel Yayıncllık.

Türküresin, H. E. (2020). Covid-19 pandemi döneminde yürütülen uzaktan eğitim uygulamalarının öğretmen adaylarının görüşleri bağlamında incelenmesi. Milli Ĕ̆itim Dergisi, 49(1), 597-618.

Ülkü, S. (2018). İlkokullarda görev yapan öğretmenlerin uzaktan eğitime yönelik tutumları [Yayımlanmamış yüksek lisans tezi]. Abant İzzet Baysal Üniversitesi.

Yenal, A. Ç. (2009). Uzaktan eğitim tutumları [Yayımlanmamış yüksek lisans tezi]. Yeditepe Üniversitesi. 
Yıldız, M. (2015). Uzaktan eğitim programlarında ders veren öğretim elemanlarının uzaktan eğitime yönelik bilgi, inanç ve uygulamaları arasındaki ilişkiler [Yayımlanmış Yüksek Lisans Tezi]. Hacettepe Üniversitesi.

Yıldız, M. ve Erdem, M. (2018). An investigation on instructors' knowledge, belief and practices towards distance education. Malaysian Online Journal of Educational Technology, 6(2), 1-20.

\section{EXTENDED ABSTRACT}

\section{Introduction.}

Implementation of educational activities by interacting with technological opportunities regardless of time and space is defined as distance education. Distance education has become the most important method of formal and non-formal education with the coronavirus (Covid-19) epidemic. This method, which was used to remove the difficulty of educating people who were previously in remote places, became a method used by countries to increase their education level after World War II. However, as obstacles arise in front of going to school, it has become necessary to use distance education methods. Face-to-face education was suspended in our country on March 16, 2020. Distance education has started as of this date. Various studies have been carried out to make distance education efficient. For this purpose, 3 TV channels started broadcasting. The Education Information Network (EBA) platform was technically supported, allowing teachers to create live classrooms and conduct lessons. Mobile applications were made available to students and parents. Again, the prepared content was made available to teachers and students online. Free data rights were defined by mobile phone operators regarding internet connection. Tablet aid was provided to students in need from various institutions and organizations, especially the Ministry of National Education. Again, EBA Support Points were created in schools, enabling students to use the facilities of the school. The effectiveness and achievement of all these activities depend on people's perceptions of distance education. Individuals with positive judgments are of great importance in increasing the success of the system. With this study, it was tried to determine the benefit perception levels of teachers regarding distance education activities and these perception levels were examined in terms of various variables. With this work; Teachers' perceptions of the benefit of distance education and the relationship between this perception and gender, educational status, school type and years of seniority were tried to be explained.

\section{Method.}

This study, which aims to determine the benefit perceptions of teachers regarding distance education activities, is a cross-sectional study conducted with the scanning model, which is a quantitative research method. The purposeful sampling method was used while determining the study group of the research. Study data were collected with a measuring tool consisting of two parts. Participants' demographic information (gender, educational status, type of school, seniority year) is included in the first part, while the second part includes the benefit perception scale for distance education developed by Ylldız (2015). This scale; It includes 
the effectiveness of learning products, richness of learning experiences, economy of the system. Data obtained online with the principle of volunteering; It was analyzed and interpreted by applying frequency, percentage, mean, standard deviation, $\mathrm{t}$ test and Anova tests.

\section{Results.}

When looking at the averages of responses to scale items, the article "space provides flexibility" has the highest average. The smallest average item appears to be "allowing for a greater number of students". When looking at the averages of the scale items according to the factors they contain; It is seen that the items containing the economics factor of the system have the highest average, while the items containing the richness of learning experiences factor have the lowest average. It was concluded that teachers' perceptions of distance education did not differ significantly according to gender factor, but female teachers had a more positive perception than male teachers. It was concluded that teachers ' perceptions of Distance Education did not differ significantly depending on the educational status factor, but that graduate teachers had a more positive perception than undergraduate teachers. It has been observed that the distance education perceptions of teachers differ according to the type of school they work in, teachers working in kindergarten have a more positive perception than teachers working in other school types and differ significantly. It was concluded that teachers' perceptions of distance education did not differ significantly according to the year of seniority factor, but teachers with a seniority of 21-30 years had a more positive perception.

\section{Discussion \& Conclusion.}

According to the research results; It is seen that teachers' perceptions and benefits of distance education are almost ambivalent. There are studies in the literature that support this result. It can be said that the unexpected and rapid transition to distance education with the pandemic process has an effect on this result. However, teachers have a positive opinion on the economics of distance education. Distance education benefit perceptions of teachers; it does not differ significantly in terms of gender, educational status, and seniority factors. However, it differs significantly in the pre-school level according to the school level served.These results agree with the literature. In the light of these results, teachers' perceptions of benefit should be high in order for the system to become more efficient. For this, this research should be repeated with a qualitative research method and the reasons for teachers' low perception of the benefits of distance education can be investigated. Arrangements can be made according to the data to be obtained. 